\title{
Prerequisites for successful succession in family company according to its successor
}

\section{Introduction}

Family firms are the oldest institutions in the business world; as such, they constitute one of the pillars of the world-wide economy. Their creation, operation, and collapse considerably affect the development of both national and global economies. The long-term perspective of running a business by a future generation as well as the combination of family-related and managerial functions result in distinct identities of said entities. It needs to be underlined that every fifth company of the Fortune 500 list is a company managed by members of one family. For example, one may mention such widely known trading companies as Walmart, car manufacturers like Volkswagen, Glencore - a natural resource commodities trader, Samsung - a producer of electronic goods, L'Oréal - a producer of beauty products, IKEA - a producer of furniture, and Lego - a manufacturer of toy blocks.

In the US, family businesses generate around 60\% of its GDP and provide nearly $80 \%$ of new jobs. However, the study's findings show that Polish family businesses generate around 10\% of Poland's GDP. Regardless of the size of a family business, its profile of production, or service, the economics literature states that succession is an indelible element for the entity to operate in its definitions of family businesses. For family businesses, succession is a prerequisite for their survival and development.

The fact that numerous Polish companies are now facing key decisions related to the transfer of power, knowledge, and property is becoming more and more obvious. The first wave of succession is coming; therefore, the company founders (those who took the risks and sacrificed their work, energy, and money

* Silesian University of Technology, Faculty of Organization and Management, Institute of Management, Administration and Logistics, e-mail: mariola.dzwigol-barosz@polsl.pl. 
to establish their businesses) are about to hand their companies over to their successors. The first intergenerational change is connected with the necessity of defining a new vision of the company by a senior member and the family as well as establishing new systems of values and formal regulations as to the property and power in the family firm.

Within the five years to come, $37 \%$ of the owners of Polish private businesses will plan to relinquish their power - this data can be found in the "Family Business Study" carried out in Poland by PwC (PricewaterhouseCoopers) in cooperation with the Instytut Biznesu Rodzinnego [Institute of Family Businesses]. Among those companies planning for succession over the next few years, a vast majority intends to keep the property and power in the hands of their families (75\%), whereas a third are planning to pass these on to younger generations (though supported by professional managers). The findings show that more than a half of the Polish family companies covered in the study $(60 \%)$ have already made their decisions as to their prospective successors (Ibrahim and Ellis, 1994, 211-212).

Succession and its planning constitute a complex process of elaborating and executing a strategic plan to transfer property and power by the owner of a family business to a chosen successor - someone who will be able to carry on the profile of the family business and expand the company in accordance with an agreed strategy.

The aim of this paper is to determine the conditions of successful succession as sought by the successors of family businesses. The following study presents research methodics as to the evaluation of the succession process combined with the author's participant observations in a researched family company as well as an in-depth particularly structured interview carried out with the successor of said company.

\section{Research methods as to determinant factors of succession}

The research involved the participant observation method and an in-depth semi-structured interview carried out with the successor of the family business. Within the scope of the participant observation, an observer attempts to "enter" a researched community in order to observe it "from inside" (Altkorn, 1998, 380). This method allows us to purposely register authentic the behavior of people in their natural environment. The subject matter of the process is to observe the individual behavior of the research subjects, while the observer's task involves recognizing, registering, and interpreting a subjective sense and social significance of said behavior. 
The participant observation involved accompanying a respondent while she performed her daily habitual tasks The observer did not confine herself to sheer registering. Some current situation-related questions were asked in order to understand how the process was run and what motives the researched person held. The aim of the participant observation was to examine the behavior of the researched person in her natural environment, every-day situations, and events for the sake of the succession process in the family business as well as the relationship between the senior member and the successor in this company.

To this end, the author (the observer) entered into contact with the researched persons, actively participated in observed situations, and sometimes prompting the subjects by behaving in a particular way to make them act and react accordingly. However, the author did not directly influence the researched people's behavior; she merely adopted one of the roles typical for the observed situations without often disclosing her real intentions to the research subjects.

The succession process in family enterprises and emotional intelligencerelated behavior are characterized by comprehensive complexity and ambiguity, which requires the researched notion to be analyzed further. To this end, qualitative interviewing was used as a research method.

The combination of interviews and observations brings numerous advantages that intertwine and allow us to comprehend other facts (www.ibrpolska.pl). Qualitative interviewing is a kind of interaction between an interviewer and a respondent. The interviewer has a general research plan; however, it is not a fixed number of questions that need to be asked in a given order and with the use of determined words. It is crucial for the interviewer to be fairly familiar with the questions to be posed; as a result, the interview may go smoothly and naturally (Babbie, 2007).

A qualitative interview is a steered and controlled conversation during which an interviewer particularly emphasizes some topics (triggered by a respondent) and consequently indicates the general direction of the conversation.

In the social science literature, one can find various interviews. The research in question involved an individual semi-structured interview (SSI). The core of said interview is to ask a series of pre-defined questions; however, a researcher is allowed to change their form and order. Thus, one may analyze the answers in depth (Promoting..., 1995). The technique of a semi-structured interview has been used to acquire some data by combining the advantages of qualitative and quantitative methods. Due to the scarce population used for selecting samples along with its specific character, the interviewer is allowed to adopt a qualitative approach and collect unique data. Nonetheless, the specific character of the researched information makes the use of a semi-structured interview scenario reasonable. 
In some research studies, it is justified to select a sample on the basis of the interviewer's own knowledge on the researched population and research aims. This type of selection is called an arbitrary or purposive sample (Babbie, 2009). A purposive sampling is used when a researcher is familiar with a population, making it easy to define the individuals who are most representative of said sample. For the sake of purposive sampling, the researcher subjectively selects individuals with the aim of finding the most-useful or the most-representative ones. The selection should focus on singling out specific and characteristic respondents in order to eliminate non-competent and insipid individuals who have little to say (Bieniok, 1999).

The observations and semi-structured interview were carried out with the successor of family business P1 in January 2017. This company was selected for research purposes on the basis of the following criteria:

- a family business is a business entity in which at least two members of the family work together for the company, at least one member of the family considerably influences the managing of the company, and family members have majority interests in the company,

- the business considers itself to be a family business,

- the family business is managed by a second generation at least (there was at least one succession that took place),

- it is a corporation (a limited liability or joint-stock company) pursuant to the Polish Code of Commercial Companies,

- it has been in operation for at least ten years,

- it is classified as a small-sized or medium-sized enterprise,

- its head office is in the Polish province of Silesia ${ }^{1}$.

The application of the above-mentioned research methods allowed the author to conduct an in-depth analysis of the area in question, with special consideration given to the following:

- a diagnosis of the factors that shaped the successor's decision as to her education-related choices,

- the influence of being raised in the entrepreneurial family on her decisions related to her professional path,

- the way the parents shaped their children's pro-business attitudes,

- the importance of the successors' competencies related to emotional intelligence,

\footnotetext{
${ }^{1}$ It was a deliberate decision to select this province for the sake of the research. The researcher assumed that the province of Silesia is known for its strong spirit of entrepreneurship and fixed business-related behavior patterns.
} 
- the crucial factors determining the succession processes,

- the role of a senior member in the succession process,

- the course of the succession process.

\section{Influence of being raised in entrepreneurial family on developing successor's professional career}

The successor of the P1 family business confirmed that her parents had influenced her education-related decisions. She also admitted that being raised in the entrepreneurial company had a great impact on her career-related decisions. The phenomenon confirmed what is propagated in various scientific studies the succession depends on the family values and upbringing models used by the parents (Aronoff et. al., 2012, 42).

A particular emphasis was placed on the upbringing methods used by the parents, since the methods considerably influenced the development of the entrepreneurial attitudes. This view has been shared by such researchers as E. Więcek-Janka, E. Aronoff, S.L. McClure, J.L. Ward, A. Surdej, M. Fretschner, and S. Weber (Aronoff et. al., 2012, 42; Grant, 1992). The emphasis was put on the time and interest the parents devoted to their children, which consequently forged a partner-like relationship between the parent and the child. This relationship plays a crucial role in the succession process.

As proven by other researchers, the successor highlights the importance of the educational influence of an entrepreneurial family on the future attitudes of the children (Barnes, 1988; Kałużna, 2009, 49-61). Equally important as to the shaping of the entrepreneurial attitudes are the methods indicated by Polish and foreign authors (Bennis and Thomas, 2002; Bieniok, 2007; Halter et. al., 2009; Safin, 2006, 21; Stradomski, 2010, 53):

- Parents encouraging children to succeed (especially in sports or at school).

- Learning how to be self-reliant (thanks to summer camps).

- Parents who establish specific models, set examples, and show opportunities (through their lifestyle as well as their personal and professional achievements).

The respondent highlights that her parents trusted her, that she was consequently granted a considerable amount of independence, and that she was encouraged to make her own decisions (with a special emphasis given to the consequences of said decisions). The success-related satisfaction and results of the failures (all being outcomes of her own decisions) forged her self-esteem, responsibility, and self-reliance. All of these are perceived as competencies required of contemporary managers. 
In the successor's opinion, the principles and models derived from her home were the best course of her social, interpersonal, and emotional education, which prepared her to fulfill her professional and personal tasks.

As to her professional career, the respondent admits to having been forced to start working for the family business to a certain degree, mainly when one considers the point in her life when she was asked to do so (at that time, the successor was a third-year student taking a full-time course load). She admits that her concerns were mainly connected to the change from full-time studies to an individual program as well as her ability to combine studies with work, her reduction of free time, and her entrance into adult life. However, she claims that her concerns were ungrounded by giving the following examples: she achieved better marks at the university, she became more organized and orderly, and (above all) she had already acquired two years of business experience upon her graduation (which gave her a competitive edge over her fellow students). The successor underlines that she obtained her MA degree when she was already holding a managerial post.

\section{Essence of successors' competencies related to emotional intelligence}

The classification of successor competencies used in the succession process implies their various origins. Providing the family enterprise with multi-generational resources and development and ensuring that the enterprise is highly efficient are, to a large extent, dependent on the relevant competence potential of its successors. Those family enterprises that anticipate the succession process should focus on the competence profiles of their successors while taking into consideration the role played by the competencies related to emotional intelligence.

The significance of the competencies in this area was underlined by L. Weroniczak (among others) who enumerated the following psychological and social skills (perceiving them as necessary for creating some space favoring an intergenerational dialogue - the latter being an element of the succession process) (Więcek-Janka, 2015, 39-53):

- communication skills,

- empathic perception,

- ability to solve conflicts through cooperation,

- understanding change processes,

- seeing diversity as a resource,

- regarding the company and the family as intertwined systems. 
The successor was presented with a set of competencies related to emotional intelligence. She was requested to indicate those competencies or competency groups that, in her opinion, were of considerable importance in the succession process.

Table 1 shows the competencies that were presented to the respondent.

Table 1

Competencies related to emotional intelligence

\begin{tabular}{|l|}
\hline \multicolumn{1}{|c|}{ SELF-AWARENESS } \\
\hline ability to recognize one's own emotions \\
\hline being aware of one's own feelings, values, or preferences \\
\hline self-esteem \\
\hline \\
\hline self-belief \\
\hline awareness of one's own abilities and opportunities \\
\hline awareness of one's own limitations \\
\hline \\
\hline ability to consciously regulate one's own emotional states \\
\hline ability to cope with stress \\
\hline ability to adjust one's own emotions to one's own norms, principles, and values \\
\hline \\
\hline being aware of other people's feelings, values, or preferences (understanding others) \\
\hline being sensitive to the feelings of other people \\
\hline being willing to help and support other people \\
\hline \\
\hline ability to express one's opinions, criticism, needs, and wishes \\
\hline ability to firmly say 'no" in a way that does not offend other people \\
\hline ability to accept criticism and evaluation \\
\hline \\
\hline argumentation skills \\
\hline effective communication \\
\hline ability to settle conflicts \\
\hline \\
\hline ability to create visions and encourage others to fulfill them \\
\hline ability to win supporters \\
\hline charisma \\
\hline \\
\hline ability to create bonds and cooperate with others \\
\hline ability to work in a group to achieve common aims \\
\hline ability to perform tasks in a group and solve problems collectively \\
\hline
\end{tabular}


Table 1 cont.

\begin{tabular}{|l|}
\hline \multicolumn{1}{|c|}{ MOTIVATION } \\
\hline self-commitment \\
\hline striving for success \\
\hline optimistic attitude \\
\hline \multicolumn{2}{|c|}{ ADAPTATION SKILLS } \\
\hline willingness to change \\
\hline willingness to take decisions and act \\
\hline willingness to act and make decisions when under pressure \\
\hline \\
\hline willingness to take responsibility for tasks and their execution \\
\hline ability to find satisfaction from performed duties \\
\hline being determined in actions \\
\hline
\end{tabular}

Source: Author's own elaboration (based on Goleman, 1996)

The respondent states that modern successors should feature each of the above-mentioned competencies to a greater or lesser extent. She thus confirms the theory promoted by numerous authors that emotional intelligence-related competencies are crucial to the succession process (Jamer, 2006, 7-9; Marjański and Sułkowski, 2009, 31; Więcek-Janka, 2015, 39-53). Nonetheless, she particularly emphasizes that self-belief and self-esteem are also necessary for managing a family company. The respondent states that a successor should be aware of his/her abilities in order to reasonably set goals and fulfill them. However, the successor should also know his/her limits in order to make use of the knowledge and experience of his/her staff. Thus, he/she may cooperate with the staff (i.e., compensating for his/her deficits). In the respondent's opinion, creating bonds in order to achieve common aims requires certain abilities to win supporters who are charged with putting the vision into practice (i.e., some leaderships skills). The successor claims that creating visions and encouraging people to fulfill them depend on communicating in the broad sense of the word. On the other hand, persuasion is a prerequisite in each change-introduction process in a company, whereas the lack of adaptation skills in an ever-changing environment implies that the effective management and development of the company are, in her opinion, impossible. The respondent underlines that the complexity of the business environment in which modern companies operate (not only family-run ones) requires that the successors have the ability to cope with stress as well as act and make decisions when under pressure (among many other crucial advantages). 


\section{Significance of factors that determine succession process}

In family companies, the succession should be a comprehensive, long-term, and meticulously planned process in which (apart from the formal requirements and competencies) one should take family values, the rules of behavior, and the traditions of the company into consideration.

The respondent was presented with a set of 11 factors that determine the succession process in a family company (as presented in Table 2 ). Her task was to indicate the factors that, in her opinion, determine the succession process to the largest extent. The successor was also encouraged to add other previously unmentioned factors that determine said process.

Table 2

Factors that determine succession process

\begin{tabular}{|c|l|}
\hline No. & \multicolumn{1}{|c|}{ FACTORS THAT DETERMINE SUCCESSION PROCESS } \\
\hline 1 & Good relationship with parents \\
\hline 2 & Good relationship between successor and other members of family \\
\hline 3 & Good relationship between successor and staff \\
\hline 4 & Good relationships with clients \\
\hline 5 & Trusting successors \\
\hline 6 & Faith in successor's skills \\
\hline 7 & Encouraging successor to become familiar with business activity \\
\hline 8 & Knowledge of trade/market \\
\hline 9 & Trade-related experience \\
\hline 10 & Education \\
\hline 11 & Clear criteria of property division \\
\hline 12 & Others (what factors?) \\
\hline
\end{tabular}

Source: Author's own elaboration

The successor picks out the following features as the determiners of the succession process:

- trusting the successor,

- faith in the successor's skills,

- good relationship with parents. 
She says that, in her case, the above-mentioned factors considerably influenced the succession process and that each of them is directly connected with the others. In the respondent's opinion, a good relationship with the parents has an immediate impact on the trust between parents and children and vice versa - members of the family trust one another, which reinforces the bonds between them. The quality of the relationship between the company founder and its successor is also highlighted by E. Venter, C. Boshoff, and G. Maas. They claim that succession-related satisfaction is strictly connected with the existence of a positive relationship between the founder/owner and his/her successor (Weroniczak, 2012, 81). The same authors also highlight that senior members of the family company should trust their potential successor, which is also confirmed by the successor herself. She claims that a family company will be transferred by the parents to the offspring whose abilities and skills they trust. She concludes that, if the relationship between the parents and children is good, then the parents will know whether their child possesses the abilities and predilections to take over the family business or whether the child is at least wishful, able, and motivated to acquire them. The respondent particularly focuses on another group of factors of essential character as to succession:

- good relationships between the successor and the remaining members of the family,

- clear criteria as to the division of property.

Leaving the above-mentioned conditions unsatisfied is one of the most frequent reasons for the short lives of family companies (Machalica, 2012, 110).

The successor states that the family company is a specific entity where having good relationships is of crucial importance; this truth is highlighted by numerous researchers (Lewandowska et. al., 2012, 121; Meijaard et. al., 2005, 12; Moorhouse, 2000; Sobiecki and Leszczewska, 2010; Stone and Dillehunt, 1978; Sułkowski and Mariański, 2009, 39; Venter et. al., 2005, 283-303; Więcek-Janka and Hadryś-Nowak, 2016, 61-72). She perceives said relationships as a valuable capital, non-existent in other companies, the capital that allows to reach a consensus in strategic issues. The successor believes that parents play key roles in such situations, as they should make their children familiar with their own expectations, intentions, and decisions. Only then will it be possible to avoid conflicts (now and in the future).

What is more, the importance of open communication in order to reinforce the family business is emphasized by the author (Fretschner and Weber, 2013, 410-428). In many cases, the succession is not a basic problem; the core problem is the willingness to start talking about this matter. Hence, the key issue is to start 
an open discussion among members of the family as to selecting a successor, even though said members are not directly engaged in the company's business activities. The owners' decisions as to succession considerably affect the financial situation of their spouses and children. This is particularly important for owners of family companies, whose decisions may influence their children's choices of careers.

The successor underlines that open communication has always been present in her family. She provides the following example - her parents had been talking about their intention to divide the property before the actual will was made. She confirms that, as a consequence, there were no misunderstandings between her and her siblings (which reinforced the whole family).

\section{Role of senior members in succession process}

Numerous researchers and practitioners in the family business environment hold the view that family company founders and owners are the main factors responsible for succession (Dźwigoł-Barosz, 2017, 131-133). While interviewed, the successor underlined that she was given power and ownership of the family business by her father. When asked about the role of the senior member in the succession process and his current role in the company, she stated that, despite being a formal owner of the company, her father holds an important job of a main counselor in the company.

The generation of senior members play a crucial role in the succession process. If the parents properly plan for succession, the probability of succession obstacles is reduced and the risk of deteriorating the company's situation due to management changes is minimized. Research conducted in the Swiss market confirms that emotions are the main reason why senior members are not in favor of succession (Hammersley and Atkinson, 2000, 138). Owners of family companies often delay the process of handing over their companies to successors since they experience considerable discomfort related to handing over to "foreign" hands (even if it means their own children) something that was achieved after so many years, something that became a part of themselves, something that defines their identity (Jakubowski, 2012, 73-74). It is thus necessary to take some actions that would promote the post-succession activity of the senior members of a family business, provided that they are still willing to be a part of the company. However, they would rather act as counselors than manage the companies, allowing the younger generation to show their best.

The above-mentioned phenomenon is confirmed by the researched successor, who explains that her father has been her mentor since the beginning of her 
career. She states that observing her father in everyday situations, being encouraged to ask about his opinions, and making use of his many years of experience as a senior member and counselor have been, in her opinion, the best business school possible. She believes that their cooperation allows them to blend their various values and experiences for the benefit of the company. The successor admits that their opinions are sometimes not unanimous. She underlines, however, that it is not a matter of conflict but more a matter of having an individual overview of numerous issues. However, the issues are in line with their common vision on how the company should be developed in the long run. The successor claims that having her own private management expert in the person of her father has been a highly comfortable situation for her, as it allows her to make use of his knowledge, experience, and competencies.

The successor's professional experience has only been developed in the family business, where she has worked as an HR officer and manager of the HR Department. She emphasizes the role of her father, who gradually prepared her to take over the company. The father showed her analyses of all of the departments of the company, with a special emphasis on financial and analytical documents, budgeting, and inspection; furthermore, he gradually delegated tasks and taskrelated responsibilities to her.

The rationality of the above-mentioned way in which business knowledge, professional tricks of the trade, or business secrets are transferred to businessmen's children is confirmed by A. Bocheński. He claims that a family business may be an educative environment. A successor candidate employed in a company who starts from the simplest tasks and goes further up the ladder as to take up managerial positions may learn practical skills from co-workers and senior members of the family company, including cooperation skills and managerial practices remaining in compliance with the values of the family who established the company. By means of a partner-to-partner dialogue, a senior member and successor can jointly create new development trends, reconciling the experience and knowledge of the company founders with the innovativeness and energy of their successors (Bracci and Vagnoni, 2011, 8).

The successor highlights the actions taken by her father (the senior member of the company) that were mainly focused on creating her image in the company; consequently, she was able to take over the helm of the company. She gives examples of such actions: publicly emphasizing her role in the company among colleagues and business partners as well as highlighting her independent successes achieved while performing her tasks, among others. She also states that the reasons and outcomes of her failures were only discussed with her father on a face-to-face basis. The successor claims that these actions were of great help 
for her, not only to establish her authority but also to forge her self-esteem and willingness to further improve her competencies.

Transferring knowledge to a successor is not an easy task - it is a rather lengthy process of raising a child and preparing him/her to take the company over. The owners of family companies have many opportunities to transfer knowledge to their children (Bocheński, 2016, 14):

- the upbringing process may involve transferring business knowledge, professional tricks of the trade, or business secrets to the children;

- employing a child in the company and encouraging him/her to perform the simplest tasks and proceed as far as accepting managerial positions may provide the child with numerous practical skills;

- in the preliminary period in which a successor acts as chairman, the successor should be supported by means of mentoring and counseling, by experience swap, or through learning practical aspects of management.

The observations and interview carried out in said family business proved that all of the above-mentioned assumptions were used in the succession process. It should be drawn to the readers' attention that similar actions as to succession planning were taken by senior members and successors of Polish SMEs (Adamska et. al., 2014), who had reviewed the first issue of an innovative tool Przewodnik po sukcesji $w$ firmach rodzinnych [Guide on succession in family companies].

On the basis of the interview with the successor and the observations carried out in the $\mathbf{P} 1$ family business, one may conclude that the succession process included the following four phases elaborated by S. Goldstein (Jaskiewicz et. al., 2014, 29-49):

- initiation: a period during which the children or potential successors familiarize themselves with the way in which the family business is operated;

- selection: a period during which the young generation is assessed and future leaders are subsequently selected. The core factors are their commitment and skills;

- education: a period when all of the attention is focused on developing the skills of future successors;

- sheer succession: a period when young successors are given any and all rights and obligations (power).

The analysis of the succession process in said family business proves that the successful implementation of the successor means not only transferring professional knowledge but also a skillfully inducting the successor into the family business (Miller and Rice, 1967, 44). 


\section{Conclusion}

As the market economy relies on family firms to a considerable extent, the succession problem has become common and pressing (Danco, 1975). The experience shows that $50 \%$ of family firms will be able to deal with successionrelated problems, whereas as few as $\mathbf{1 5 \%}$ of the companies will manage to hand the company over to a third generation (Tomski, 2011, 147).

Over the last few years, the owners of family businesses in Poland have systematically become more and more aware of the role of succession. The entrepreneurs have found out that inheriting a company is an inevitable process. Furthermore, they should not assume that the next generations will be willing to actively participate in the succession process. On the basis of the reference literature, one can presume that a family company based on common values is one of the best education methods for children. Working for a family company allows young people to fulfill their professional ambitions. Owing to the expert knowledge acquired while studying, they are given an opportunity to develop the company and maximize profits. Young people are more ready to take risks and more open to new ideas and innovations. Their parents' experience combined with the next generation's commitment and readiness for changes often bring about outstanding results. According to the managers of the family business under study, this multi-generational cooperation for the sake of the company is deeply inspiring. Parents can see that this investment is reasonable, as many generations will benefit from the companies (Lansberg, 1983, 39-49).

The research conducted by the author in the P1 family company shows that the parents' influence on their children's educational paths was of critical importance. It also shows that the successor's upbringing in the family company shaped her professional decisions considerably. The applied research methods indicate that an entrepreneurial company greatly affects the career-related decisions of successors and the development of entrepreneurial attitudes. The research also showed that it is essential to have competencies related to emotional intelligence in the succession process. The importance of the factors shaping the process in the largest extent is underlined.

On the basis of the conducted interview and observations, the succession process was shown along with a special emphasis on its four phases. Furthermore, the key role of a senior family in the succession process was highlighted. It needs to be emphasized that succession is not a one-time event. Succession is a long process that involves transfer of knowledge, power, and ownership (Adamska et. al., 2014; 30). The complexity of the process proves that all of the succession-related actions were properly planned. In order to ensure the 
continuity of the competent behavior, it is necessary that both senior members and successors are fully committed; thus, the family companies will be able to operate in the long run.

\section{References}

[1] Adamska, M., Bocheński, A., Iskierka-Kasperek, E., Kołodziej, R., Marjański, A., Rataj, P. and Tiahnybok, M. (2014) Przewodnik po sukcesji w firmach rodzinnych. Kompendium wiedzy, Kraków: PM Doradztwo Gospodarcze Sp. z o.o.

[2] Altkorn, J. (ed.) (1998) Podstawy marketingu, Kraków: Instytut Marketingu.

[3] Aronoff, C.E., McClure, S.L., Ward, J.L. and Surdej, A. (eds.) (2012) Sukcesja w firmach rodzinnych, Kraków: Wydawnictwo MiP.

[4] Babbie, E. (2007) Badania społeczne w praktyce, Warszawa: WN PWN.

[5] Babbie, E. (2009) Podstawy badań społecznych, Warszawa: WN PWN.

[6] Barnes, L.B. (1988) 'Incongruent hierarchies: Daughters and Younger Sons as Company CEOs', Family Business Review, March, no. 1.

[7] Bennis, W.G. and Thomas, R.J. (2002) 'Crucibles of Leadership', Harvard Business Review, vol. 80, no. 9, pp. 39-45.

[8] Bieniok, H. (ed.) (1999) Metody sprawnego zarządzania. Planowanie, motywowanie, organizowanie, kontrola. Jak zarządzać w praktyce, Warszawa: Placet.

[9] Bieniok, H. (2007) 'Kształtowanie postaw przedsiębiorczych młodzieży w rodzinie, szkole i uczelni', in Wachowiak, P., Dąbrowski, M., and Majewski, B. (eds.) Kształtowanie postaw przedsiębiorczych a edukacja ekonomiczna, Warszawa: Fundacja Promocji i Akredytacji Kierunków Ekonomicznych.

[10] Bocheński, A. (2016) 'Zarządzanie wiedzą w firmie rodzinnej', Relacje. Magazyn Firm Rodzinnych, nr 4(19), p. 14.

[11] Bracci, E. and Vagnoni, E. (2011) 'Understanding Small Family Business Succession in Knowledge Management Perspective', The IUP Journal of Knowledge Management, pp. 8-10.

[12] Danco, L. (1975) Beyond survival: A business owner's guide for success, Cleveland: University Press.

[13] Dźwigoł-Barosz, M. (2017) 'Niwelowanie luk w procesie sukcesji przedsiębiorstw rodzinnych', Zeszyty Naukowe Politechniki Śląskiej Organizacja i Zarzadzanie, z. 101, pp. 131-133.

[14] Fretschner, M. and Weber, S. (2013) 'Measuring and Understanding the Effect of Entrepreneurial Awareness Education', Journal of Small Business Management, vol. 51, no. 3, pp. 410-428.

[15] Goleman, D. (1996) Emotional Intelligence: Why It Can Matter More Than IQ, New York: Bantam Books. 
[16] Grant, W.T. (1992) 'Consortium on the School - Based Promotion of Social Competence. Drug and Alcohol Prevention Curricula', in Hawkins, J.D., Catalano, R.F., Jr., Communities That Care, San Francisco: Jossey-Bass.

[17] Halter, F., Schrettle, T. and Baldegger, R. (2009) Effective Succession Management: A study of emotional and financial aspects in SMEs, Zürich: Credit Suisse.

[18] Hammersley, M. and Atkinson, P. (2000) Metody badań terenowych, Poznań: Zysk i S-ka.

[19] http://www.ibrpolska.pl/raporty/raport-testowy-2/, 26.02.2014.

[20] Ibrahim, A.B. and Ellis, W.H. (1994) Family Business Management. Concepts and Practice, Iowa: Kendall/Hunt Publishing Company Dubuque.

[21] Jakubowski, J. (2012) 'Emocje w firmie rodzinnej' in Firma w rodzinie czy rodzina w firmie. Metodologia wsparcia firm rodzinnych, Warszawa: PARP, pp. 73-74.

[22] Jamer, J. (2006) 'Sukcesja własności i władzy w firmie rodzinnej', Biznes Rodzinny $w$ Polsce, nr 5, pp. 7-9.

[23] Jaskiewicz, P., Combs, J.G. and Rau, S.B. (2014) 'Entrepreneurial legacy: Toward a theory of how some family firms nurture transgenerational entrepreneurship', Journal of Business Venturing, vol. 30, pp. 29-49.

[24] Kałużna, H. (2009) 'Firmy rodzinne w XXI wieku - specyfika i sukcesja', Zeszyty Naukowe SGGW. Ekonomika i Organizacja Gospodarki Żywnościowej, nr 75, s. 49-61.

[25] Lansberg, I.S. (1983) 'Managing Human Resources in Family Firms: The Problem of Institutional Overlap', Organizational Dynamics, vol. 12, no. 1, pp. 39-49.

[26] Lewandowska, A., Greser, J. and Jakubowski, J. (2012) 'Sukcesja w firmie rodzinnej', in Firma w rodzinie czy rodzina w firmie. Metodologia wsparcia firm rodzinnych, Warszawa: PARP, p. 121.

[27] Machalica, W. (2012) 'Samorozwój', in Firma w rodzinie czy rodzina w firmie. Metodologia wsparcia firm rodzinnych, Warszawa: PARP, pp. 110-113.

[28] Marjański, A. and Sułkowski, Ł. (2009) Firmy rodzinne - jak osiągnąć sukces w sztafecie pokoleń, Warszawa: Wydawnictwo Poltext.

[29] Meijaard, J., Uhlaner, L., Flören, R. Diephuis, R. and Sanders, B. (2005) 'The relationship between successor and planning characteristics and the success of business transfer in Dutch SMEs', EIM Business \& Policy Research, Zoetermeer, pp. 12-13.

[30] Miller, E. and Rice, A.K. (1967) Systems of Organizations, London: Tavistock.

[31] Moorhouse, J. (2000) Podstawy marketingu, Warszawa: Pret S.A.

[32] Niedbała, E. (2002) 'Firmy rodzinne - obiekt badawczy', MBA, no. 5, p. 44.

[33] Promoting Emotional Competence in School-Aged Children: The Effects of the PATHS Curriculum (1995), Development and Psychopatbology, 1995, vol. 7. 
[34] Safin, K. (2006) Przedsiębiorstwa rodzinne - istota i zachowanie strategiczne, Wrocław: Wydawnictwo Akademii Ekonomicznej im. Oskara Langego.

[35] Sobiecki, R. and Leszczewska, K. (2010) Firmy rodzinne w Polsce - sposób na sukces, CDR w Brwinowie.

[36] Stone, K.F. and Dillehunt, H.Q. (1978) 'Self Science: The Subject Is Me', Santa Monica: Goodyear Publishing Co.

[37] Stradomski, M. (2010) Finansowanie obce firm rodzinnych na rynku niedoskonałym, Warszawa: PWE.

[38] Sułkowski, Ł. and Mariański, A. (2009) Firmy rodzinne. Jak osiagnąć sukces w sztafecie pokoleń, Warszawa: Wydawnictwo Poltext.

[39] Tomski, P. (2011) 'Programowanie przyszłości biznesu w oparciu o więzi rodzinne - wybrane problemy sukcesji', Przedsiębiorczość i Zarządzanie, t. 12 , z. 7, pp. 137-150.

[40] Venter, E., Boshoff, C. and Maas, G. (2005) 'The Influence of Successor Related Factors on the Succession Process in Small and Medium Sized Family Business', Family Business Review, vol. 18, no. 4, pp. 283-303.

[41] Weroniczak, L. (2012) Dialog międzypokoleniowy, in Firma w rodzinie czy rodzina w firmie. Metodologia wsparcia firm rodzinnych, Warszawa: PARP.

[42] Więcek-Janka, E. (2014) 'Kompetencje menedżerskie sukcesorów inżynierów w firmach rodzinnych', Przedsiębiorczość $i$ Zarządzanie, t. XV, z. 8, cz. II, pp. 139-155.

[43] Więcek-Janka, E. (2015) Bariery w procesie sukcesji w opinii sukcesorów firm rodzinnych (wyniki badań), Przedsiębiorczość i Zarządzanie, t. XVI, z. 7, cz. I, pp. 39-53.

[44] Więcek-Janka, E. and Hadryś-Nowak, A. (2016) 'Kompetencje sukcesorskie - profil wstępny', Przedsiębiorczość i Zarządzanie, t. XVII, z. 6, cz. III, pp. 61-72. 